\title{
STUDIUM PORÓWNAWCZE TRZECH FAL POLSKIEJ EMIGRACJI: PO II WOJNIE ŚWIATOWEJ, OKRESU SOLIDARNOŚCIOWEGO I PO AKCESJI DO UNII EUROPEJSKIEJ \\ Konferencja Naukowa \\ LUBLIN, 27 PAŹDZIERNIKA 2015 R.
}

W dniu 27 października 2015 r. w Lublinie, w Instytucie Europeistyki Wydziału Prawa, Prawa Kanonicznego i Administracji Katolickiego Uniwersytetu Lubelskiego Jana Pawła II, odbyła się ogólnopolska konferencja naukowa pt. Studium porównawcze trzech fal polskiej emigracji: po II wojnie światowej, okresu solidarnościowego i po akcesji do Unii Europejskiej. Została ona zorganizowana przez Katedrę Prawa Unii Europejskiej KUL, Wydział Prawa, Prawa Kanonicznego i Administracji KUL, Fundację Rozwoju KUL, Fundację Konrada Adenauera oraz Centrum Badań nad Europejskim Prawem i Polityką Migracyjną KUL.

Konferencja składała się z dwóch paneli merytorycznych, a jej otwarcia dokonał dr hab. Krzysztof Wiak, prof. KUL, Prodziekan Wydziału Prawa, Prawa Kanonicznego i Administracji KUL.

W ramach pierwszej części Konferencji, której przewodniczyła dr hab. Elżbieta Szczot, prof. KUL, Prezes Oddziału Lubelskiego Polskiego Towarzystwa Studiów Europejskich, zastanawiano się nad przyczynami, przebiegiem i kierunkami migracji obywateli polskich oraz ich statusem na terytorium państw przyjmujących $\mathrm{w}$ okresie po zakończeniu II wojny światowej oraz w tzw. okresie solidarnościowym.

Referat otwierający nt. Emigracja polska po II wojnie światowej - uwarunkowania historyczno-polityczne, wygłosił dr hab. Sławomir Łukasiewicz, Dyrektor Instytutu Europeistyki KUL (KUL, Instytutu Pamięci Narodowej-Oddział w Lublinie). Rozważania zawarte w wystąpieniu koncentrowały się wokół analizy uwarunkowań funkcjonowania polskiej emigracji politycznej w państwach tzw. bloku zachodniego.

Kolejny referat, wygłoszony przez dra hab. Patryka Pleskota (Państwowa Wyższa Szkoła Zawodowa w Oświęcimiu, Instytut Pamięci Narodowej-Oddział w Warszawie) pt. Emigracja solidarnościowa-uwarunkowania 
historyczno-polityczne, dotyczył migracji Polaków oraz ich przyczyn i skali zjawiska w tzw. okresie solidarnościowym.

Ostatnie w tej części Konferencji wystąpienie pt. Geografia emigracji polskiej po II wojnie i w okresie "Solidarności" wygłoszone zostało przez dra hab. Janusza Wróbla (Instytut Pamięci Narodowej - Oddział w Łodzi). Referent skoncentrował się w swoim wystąpieniu na wskazaniu kierunków migracji oraz państw docelowych.

Druga część Konferencji, którą prowadziła dr Edyta Krzysztofik ( KUL) zawierała rozważania poświęcone migracji obywateli RP po akcesji Polski do Unii Europejskiej.

Pierwszy referat w ramach tej sesji nt. Obywatelstwo Unii Europejskiej i prawa migracyjne obywateli państw członkowskich wygłosiła dr Renata Maria Pal, (KUL). Referat miał charakter wprowadzający do dalszych rozważań podejmowanych $\mathrm{w}$ drugiej części obrad i dotyczył pojęcia obywatelstwa UE oraz jego wpływu na migrację poakcesyjną.

Następnie dr Edyta Krzysztofik w swoim wystąpieniu zajęła się pojęciem i prawami pracowników migrujących oraz wpływem regulacji unijnych na skalę migracji obywateli RP oraz konsekwencjami prawnymi tego zjawiska.

Kolejny referat, zatytułowany Polskie migracje sezonowe do Niemiec jako struktury długiego trwania, wygłosiła mgr Maria Piechowska (Ośrodek Badań nad Migracjami UW),. Prelegentka w prelegentka swoim wystąpieniu wskazała na problemy związane $\mathrm{z}$ tego typu migracjami oraz zaprezentowała ich charakter i rozmiar.

Następnie dr Marcin Sokołowski (UAM) wygłosił referat pt. Miejsce zamieszkania dziecka jako przesłanka właściwości sadu w rodzinnych sprawach transgranicznych w Unii Europejskiej, skupiając się na wpływie swobód rynku wewnętrznego na prawo rodzinne i właściwość sądową. W olejnym referacie, zatytułowanym Zasady licencjonowania banków w systemie jednolitego paszportu europejskiego, dr Michał Chajda (Wyższa Szkoła Finansów i Prawa w Bielsku-Białej) zajął się swobodą przedsiębiorczości. Prelegent skupił się na problematyce licencjonowania banków w Polsce i w Niemczech.

Następnie głos zabrała dr Małgorzata Ganczar (KUL), która zaprezentowała referat pt. Zakładanie działalności gospodarczej w Niemczech. Prelegentka skupiła się na zasadach prowadzenia działalności gospodarczej w Niemczech oraz porównała je do reguł obowiązujących na terytorium RP.

Ostatni referat w ramach drugiej sesji Konferencji nt. Roli Polski i Niemiec w ksztattowaniu humanitarnej polityki migracyjnej Unii Europejskiej wy- 
głosiła dr Anna Kosińska (KUL). Skoncentrowała swoje wystąpienie wokół aktualnej polityki migracyjnej UE oraz problemu uchodźców.

Obrady ciekawa zakończone zostały żywą dyskusją, w ramach której odniesiono się do wszystkich zagadnień poruszonych w referatach. Konferencję podsumował i dokonał jej zamknięcia dr hab. Marcin Szewczak, prof. KUL, Kierownik Katedry Prawa Unii Europejskiej KUL.

Renata Maria Pal

* Dr, Katolicki Uniwersytet Lubelski Jana Pawła II, e-mail: palren@kul.pl. 